Miroslav Cvetanović ${ }^{1}$, Jasmina Cvetanović ${ }^{2}$, Mirjana Mihajlovska ${ }^{3}$, Vasko Tošić ${ }^{3}$, Arsenijević $\mathrm{V}^{3}$

\title{
FAKTORI RIZIKA ZA KRVARENJE IZ AKUTNE MUKOZNE LEZIJE KOD POLITRAUMATIZOVANIH I KRITIČNO OBOLELIH
}

\begin{abstract}
SAŽETAK: Krvareća mukozna lezija izazvana stresom je lezija sluzokože koja se razvija kao posledica sloma barijere želudačne sluznice kod kritično obolelih i politraumatizovanih pacijenata i predstavlja potencijalno smrtonosnu komplikaciju. Profilaktički tretman kod pacijenata sa faktorima rizika značajno smanjuje učestalost krvarenja. Profilaksa smanjuje krvarenje iz akutne mukozne lezije za više od $90 \%$ u odnosu na procenjeni rizik. U grupi pacijenata kojima je potrebna operacija ukupna stopa smrtnosti je još uvijek oko 34\%. Pacijenti sa sepsom i oni na dugotrajnoj arteficijelnoj ventilaciji su najrizičnija grupa. Izbor profilaktičkog sredstva u ovoj oblasti, posebno za grupu sa anamnestičkom istorijom ulceracija ili gastrointestinalnog krvarenja, još uvek ostaje dilema.
\end{abstract}

Ključne reči: akutna mukozna lezija, krvarenje, profilaksa, bolesnici sa teškom traumom, kritično bolesni pacijenti

Stres ulkus, oštećenje sluzokože izazvano stresom ili akutna mukozna lezija je lezija sluzokože koja se javlja u dva oblika: difuzno površinsko oštećenje sluzokože ili duboke fokalne lezije koje prodiru u submukozu i pojavljuju se uglavnom na korpusu ili fundusu želuca. Pojedini autori navode da čak 75\% do $100 \%$ pacijenata ima neki oblik gastrointestinalne lezije koja se može verifikovati u prva 24 sata. Klinički relevantni oblici takvih lezija (krvarenje i mnogo manje učestale perforacije, koje zahtevaju transfuziju krvi ili hirurško lečenje) javljaju se kod 6-10\% pacijenata u jedinicama intenzivnog lečenja ${ }^{1}$. I etiologija i patofiziologija lezija se odnose na više faktora i nisu dovoljno objašnjeni. Ishemija i reperfuzija dovode do sloma barijere sluznice. U takvim uslovima dolazi do razaranja sluzokožnog sloja koji služi za eliminisanje potencijalnih toksina i smanjenja sinteze prostaglandina. Povećana koncentracija radikala kiseonika

\footnotetext{
KBC "Dr Dragiša Mišović”

2 Gradski zavod za hitnu pomoć, Beograd

3 Klinika za hirurgiju Urgentnog centra KCS
} 
uzrokuje upalu, ćelijsku smrt i dalje izlučivanje inflamatornih citokina. Faktori rizika za gastrointestinalno krvarenje iz takve lezije su: arteficijelna ventilacija koja traje duže od 48 sati, koagulopatija, značajna hipotenzija, sepsa, dugotrajno prisustvo nazogastrične sonde i obustava peroralnog unosa ${ }^{2}$, akutna insuficijencija jetre, akutna i hronična bubrežna insuficijencija, teška trauma glave, opekotine koje pokrivaju više od 30\% tela, hronični alkoholizam, duge i opsežne hirurške procedure, tretman koji uključuje kortikosteroide i neke antikoagulante, transplantaciju organa. Ovi pacijenti i pacijenti stariji od 65 godina ili oni koji imaju istoriju gastritisa ili ulkusne bolesti kandidati su za profilaktički tretman akutne mukozne lezije.

Klinički, pored pojave krvi u sadržaju nazogastrične sonde, melena ili neobjašnjiva hipotenzija (spontano smanjenje sistolne tenzije za $20 \mathrm{~mm} \mathrm{Hg}$ ili više), povećanje srčane frekvencije za više od 20 otkucaja u minutu i pad više od $2 \mathrm{~g} / \mathrm{dL}$ u nivou hemoglobina mogući su prediktori gastrointestinalnog krvarenja ${ }^{1,3}$. Drugi mogući indikator za krvarenje je broj transfuzija krvi koje, ako se smanji za 2, ne rezultiraju odgovarajućim povećanjem nivoa hemoglobina.

Profilaksa krvarenja uključuje kliničke parametre i praćenje rezultata testova krvi i elektrolita, izbegavanje lokalne iritacije (sonde, antiinflamatorni lekovi, aspirin) i ograničenu primenu vazopresora, kad god je moguće, jer mogu pogoršati gastrointestinalnu ishemiju. Vazopresori uzrokuju povećanje arterijske tenzije na račun mezenterične perfuzije. Brojne studije su pokazale da enteralni unos započet u prva 24 sata nakon traume ili početka bolesti ima isti efekat kao i profilaksa H2-receptora ili PPI. Takve tvrdnje, međutim, nisu potvrđene multicentričnim ili metaanalitičkim studijama ${ }^{2,4}$. Pored toga, poznata je činjenica da mnogi hirurški pacijenti jednostavno ne mogu započeti enteralni unos u prva 24 sata (npr. pacijenti sa akutnim pankreatitisom, pacijenti koji su bili podvrgnuti invazivnim hirurškim procedurama na digestivnom traktu itd.).

Američko udruženje farmaceuta pripremilo je smernice za farmakološki profilaktički tretman protiv pojave akutne mukozne lezije i njenih komplikacija. Preporučuje se farmakološka profilaksa za sve odrasle pacijente u jedinicama intenzivne nege koji:

1. imaju koagulopatiju,

2. zahtevaju mehaničku ventilaciju duže od 48 sati,

3. su u prošlosti imali gastrointestinalni ulkus ili krvarenje u prethodne 3 godine,

4. imaju najmanje dva od sledećih faktora rizika:

- sepsa

- borave u ICU duže od 7 dana,

- akutno krvarenje bilo kog izvora u periodu dužem od 5 dana,

- dobijaju $250 \mathrm{mg}$ hidrokortizona (ili drugog ekvivalentnog kortikosteroida) $)^{1,3,5}$.

Najčešće korišćeni lekovi za prevenciju akutne mukozne lezije na Centrima traume I nivoa u SAD i drugim zemljama visokorazvijenih medicinskih sistema su 
antagonisti H2-receptora (67\%) i PPI samo kod pacijenata sa istorijom gastrointestinalne ulkusne bolesti i/ili krvarenja iz gornjeg dela digestivnog trakta.

Sukralfat se koristi u značajna $24 \%$ slučajeva. Omeprazol i Pantoprazol se koriste za prevenciju u više od $10 \%$ slučajeva, i to samo za pacijente sa visokim rizikom od krvarenja prema Zinner skoru. Kod pacijenata visokog rizika (koagulopatija, respiratorna insuficijencija), inhibitori protonske pumpe (PPI) su sve češći izbor, sa potencijalno povoljnim rezultatima. PPI pokazuju određena farmakokinetička svojstva koja im daju prednost u odnosu na druge lekove, iako objavljene serije ne dokazuju superiornost PPI u odnosu na antagoniste $\mathrm{H} 2$ receptora $^{5}$.

Nega pacijenata u jedinicama intenzivne nege kod kojih postoji rizik od krvarenja iz stresnog ulkusa (akutne mukozne lezije) je vitalni deo lečenja. Zbog toga, osoblje u jedinicama intenzivne nege mora biti visokokvalifikovano u svojoj oblasti, kako bi bili prepoznati pacijenti sa visokim rizikom. Na ove pacijente treba obratiti posebnu pažnju prilikom postupaka i procedura (nazogastrična sukcija, aspiracija sadržaja, enteralna ishrana). Takođe, vitalni parametri treba da budu registrovani često, pa i svakih 60 min. kako bi se blagovremeno alarmirao lekar.

Bez obzira na profilaktički tretman izbora, veoma mali broj pacijenata zahteva hirurško lečenje krvarenja iz stresnog ulkusa (nešto više od 2\%). Od operisanih pacijenata, oko $47 \%$ se nalazi u grupi onih sa istorijom ulkusne bolesti i/ili krvarenja, tako da samo oko 1,5\% pacijenata koji su imali lezije ili krvarenja mukozne lezije nastale de novo zahtevaju hirurški tretman.

Pacijenti sa sepsom zbog sistemskih efekata predstavljaju poseban izazov za profilaksu i lečenje gastrointestinalnog krvarenja uzrokovanog akutnim lezijama sluznice. Kod septičnih, osnovno stanje ili trauma sama po sebi obično pogoduje takvom krvarenju, a takođe i dugotrajno zadržavanje u jedinicama intenzivne nege i oslobađanje i veća koncentracija proinflamatornih medijatora, kao i agresivna terapija koja zahteva lečenje sepse (vazopresori, mehanička ventilacija, kortikosteroidi).

Gastrointestinalno krvarenje iz akutnih lezija sluznice kod teške traume i kritično bolesnih pacijenata obično je rezultat višestrukih faktora rizika, od kojih su početni hipotenzija, hipoksija i ishemija sluzokože. Krvarenje u kombinaciji sa sepsom i veštačkom ventilacijom pojavljuje se u roku od oko dve nedelje od traume ili početka bolesti.

Sepsa u kombinaciji sa dugotrajnom respiratornom podrškom je najčešći uzročni faktor za krvarenje mukozne lezije izazvane stresom, što objavljuje većina autora. Jang et al. specificiraju da je u grupi od 574 pacijenta koji su imali teške komplikacije trauma koje su rezultirale sepsom, 10,8\% pacijenata imalo je manifestaciju krvarenja iz stresnog ulkusa u poređenju sa $0,3 \%$ iz grupe pacijenata koji nisu razvili sepsu. Ukupna smrtnost u različitim studijama je u proseku $22,5 \%$. Krvarenje je uzrok smrti u manje od 3\% slučajeva, što odgovara rezultatima kohortne studije sprovedene na 2252 pacijenta (Cook et al). Fadaak navodi da je u više od 50\% pacijenata sa teškim 
traumama i opekotinama, koje pokrivaju više od 33\% tela, kod kojih je došlo do smrtnog ishoda, na obdukciji ${ }^{3,4,5}$ otkrivena lezija sluznice u rasponu od površinske promene do duboke submukozne nekroze.

Brojne studije navode različite podatke o broju pacijenata sa klinički značajnim krvarenjem. U 27 randomiziranih studija, učestalost krvarenja kreće se od $2 \%$ do $3 \%$. Prospektivne kohortne studije i šest randomiziranih studija navode iste faktore rizika za krvarenje; međutim, nema dovoljno studija o predviđanju krvarenja kod pojedinačnih pacijenata. Navedeni faktori su razumni prediktori rizika krvarenja ${ }^{6,7}$. Pored toga, težina traume / bolesti predstavlja faktor rizika primarnog krvarenja usled hipoksije, reperfuzije i oslobađanja visoke koncentracije proinflamatornih medijatora.

Zinnerov bodovni sistem je dobar prediktor za krvarenje iz stresnog ulkusa. Očigledno je da profilaksa ima značajan uticaj na smanjenje krvarenja iz lezija sluzokože, kao što su utvrdili autori studija objavljenih u poslednjih 10-15 godina. Na primer, serija pacijenata, u grupi I prema Zinneru, pokazuje da je među 27,3\% pacijenata koji su bili izloženi riziku od krvarenja 4,9\% imalo aktivno krvarenje, dok je u grupi II $7 \%$, a u grupi III 13\% pacijenata krvarilo. Prema tome, ukupna incidencija krvarenja za rizične pacijente je $8,5 \%$ kod većine autora ${ }^{1,7}$.

Izbor profilaktičkog sredstva može takođe biti važan faktor za prevenciju krvarenja, posebno u slučajevima sa anamnezom krvarenja u prethodnoj godini ili sa istorijom ulkusne bolesti, te treba insistirati na pravilno i detaljno uzetoj anamnezi. Profilaktički tretman treba da se nastavi nekoliko nedelja nakon što faktori rizika prestanu da postoje, posebno ako su rizici kombinovani. Početak ranog enteralnog unosa je važan, jer prisustvo hrane ima stimulativni efekat na proliferaciju sluzokože i splanhničnu cirkulaciju, što služi kao odlična prevencija protiv obilnijih krvarenja izazvanih stres ulkusom ${ }^{8}$.

Podaci pokazuju da profilaksa smanjuje broj pacijenata koji krvare od stresnog ulkusa, iako ne utiče na smrtnost kod pacijenata koji prokrvare, bez obzira na profilaksu. Kod ovih pacijenata, stopa smrtnosti je i dalje izuzetno visoka $(34,5 \%)$, posebno ako je potrebna hirurška procedura, kada smrtnost prelazi i 50\%. Iz tog razloga, hirurški rizik je prilično visok. Faktori rizika za hirurški zahvat su: HGB $<80 \mathrm{~g} / \mathrm{L}, \mathrm{BP}<80 \mathrm{~mm} \mathrm{Hg}, \mathrm{HR}>120$ bpm, CRP $>200$, D-dimer $>1000$, APACHE II $>10$, ponavljane hirurške intervencije ${ }^{9}$.

\section{Zaključak}

Profilaktički tretman značajno smanjuje učestalost klinički relevantnog krvarenja izazvanog stresom kod teških trauma i kritično bolesnih pacijenata, a svaka od njih treba da ima protokol za profilaksu za različite kritične grupe. Krvarenje iz akutne lezije sluznice još uvek predstavlja pretnju za potencijalno smrtonosne komplikacije teške traume ili kritičnih stanja. Posebnu pažnju treba posvetiti izboru profilaktičkih 
sredstava za pojedine pacijente, jer dosadašnja istraživanja ne daju nikakve izričite sugestije o pristupu selekciji profilaktičkih agenasa.

\section{Literatura}

1. Barkun AN, Bardou M, Pham CQ, Martel M. Proton pump inhibitors vs histamine 2 receptor antagonists for stress-related mucosal bleeding prophylaxis in critically ill patients: a meta-analysis. Am J Gastroenterol 2012; 107: 507-520.

2. Alhazzani W, Alenezi F, Jaeschke RZ, Moayyedi P, Cook DJ. Proton pump inhibitors versus histamine 2 receptor antagonists for stress ulcer prophylaxis in critically ill patients: a systematic review and meta-analysis. Crit Care Med 2013; 41: 693-705.

3. Dellinger RP, Levy MM, Rhodes A, et al. Surviving Sepsis Campaign Guidelines Committee including the Pediatric Subgroup. Surviving sepsis campaign: international guidelines for management of severe sepsis and septic shock: 2012. Crit Care Med 2013; 41: 580-637.

4. Eisa N, Bazerbachi F, Alraiyes AH, Alraies MC. Do all hospitalized patients need stress ulcer prophylaxis? Cleveland Clinic Journal of Medicine. 2014 January;81(1): 23-25.

5. Filion KB, Chateau D, Targownik LE, Gershon A, Durand M, Tamim H, Teare GF, Ravani P, Ernst P, Dormuth CR. Proton pump inhibitors and the risk of hospitalisation for community-acquired pneumonia: replicated cohort studies with meta-analysis. Gut. 2014; 63: 552-558.

6. Eom CS, Jeon CY, Lim JW, Cho EG, Park SM, Lee KS. Use of acid-suppressive drugs and risk of pneumonia: a systematic review and meta-analysis. CMAJ. 2011; 183: 310-319.

7. Khorvash F, Abbasi S, Meidani M, Dehdashti F, Ataei B. The comparison between proton pump inhibitors and sucralfate in incidence of ventilator associated pneumonia in critically ill patients. Adv Biomed Res. 2014; 3: 52.

8. Buendgens L, Koch A, Tacke F. Prevention of stress-related ulcer bleeding at the intensive care unit: Risks and benefits of stress ulcer prophylaxis. World J Crit Care Med. 2016 Feb 4; 5(1): 57-64.

9. Mercer DW, Goede MR. Management of stress ulcers. UpToDate, March, 2019. 